\title{
PROBLEMATIKA PENYELESAIAN SENGKETA KEWENANGAN LEMBAGA NEGARA OLEH MAHKAMAH KONSTITUSI
}

\author{
Janpatar Simamora*
}

Bagian Hukum Tata Negara,

Fakultas Hukum Universitas HKBP Nommensen, Medan

Jalan Dr. Sutomo No. 4A Medan, Sumatera Utara 20234

\begin{abstract}
According to Article 24C verse (1) of the 1945 Constitution, Constitutional court has an authority to examine the dispute among the state institution in which its authority is given by the constitution directly. But there is a certain problem in practice which is related to definition of "state institution" and "authorities are granted the Constitution" in the 1945 Constitution. This condition opens a debate the interpretation in executing the settlement on authority dispute among the institutions. In addition, should be considered the settlement of disputes the authority of institutions, whose authority derived from regulation other than the Constitution.
\end{abstract}

Keywords: state institution, authority dispute, legal standing, Constitution.

\section{Intisari}

Menurut ketentuan Pasal 24C ayat (1) UUD NRI Tahun 1945, penyelesaian sengketa kewenangan lembaga negara yang kewenangannya diberikan oleh UUD merupakan kewenangan Mahkamah Konstitusi. Namun dalam praktiknya, proses penyelesaian sengketa kewenangan lembaga negara menghadapi problem tersendiri seiring tidak adanya batasan ruang lingkup dan definisi "lembaga negara" dan frasa "kewenangannya diberikan UUD" secara pasti dalam UUD NRI Tahun 1945. Situasi ini pada akhirnya menimbulkan multitafsir yang berpotensi mengakibatkan tidak efektifnya penyelesaian sengketa kewenangan lembaga negara di Indonesia. Selain itu, perlu dipikirkan mekanisme penyelesaian sengketa kewenangan lembaga yang kewenangannya bersumber dari peraturan selain UUD.

Kata Kunci: lembaga negara, sengketa kewenangan, kedudukan hukum, UUD.

\section{Pokok Muatan}

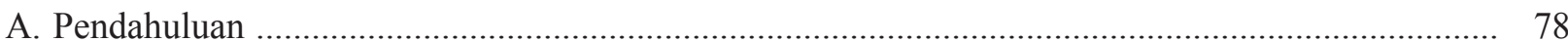

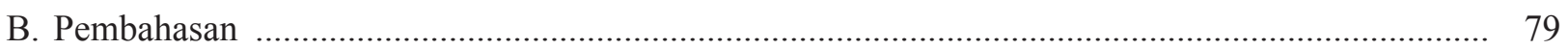

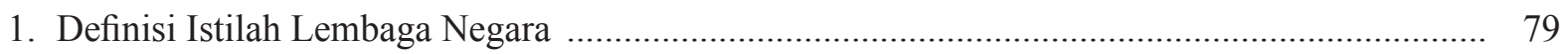

2. Lembaga yang Disebutkan dan Diatur Kewenangannya dalam UUD NRI Tahun 1945 ............ 81

3. Batasan Lembaga Negara yang Memiliki Kedudukan Hukum dalam Perkara Sengketa Kewenangan Lembaga Negara .................................................................................. 86

4. Problematika Penyelesaian Sengketa Kewenangan Lembaga Negara 88

C. Penutup 


\section{A. Pendahuluan}

Salah satu kewenangan Mahkamah Konstitusi (MK) sebagaimana diatur secara eksplisit dalam Pasal 24C ayat (1) ${ }^{1}$ adalah memutus sengketa kewenangan lembaga negara yang kewenangannya diberikan oleh Undang-Undang Dasar (UUD). Sejalan dengan ketentuan dimaksud, maka secara konstitusional MK berwenang mengadili setiap perkara sengketa kewenangan antar lembaga negara yang kewenangannya diberikan oleh UUD. Konsep semacam ini juga ditemukan di sejumlah negara seperti Austria yang menempatkan penyelesaian sengketa kewenangan lembaga negara berkenaan dengan isu kewenangan konstitusional di bawah kewenangan $\mathrm{MK}^{2}$ Adanya pengaturan masalah penyelesaian sengketa kewenangan lembaga negara lewat jalur peradilan sebagaimana digariskan menjadi ranah kewenangan MK merupakan sebuah terobosan baru dalam rangka mengantisipasi terjadinya konflik kewenangan antar lembaga negara.

Didasarkan pada perspektif historis ketatanegaraan Indonesia, mekanisme pengaturan penyelesaian sengketa kewenangan lembaga negara belum pernah ditemukan sama sekali. Dari sekian UUD atau konstitusi ${ }^{3}$ yang pernah berlaku di Indonesia, baik UUD 1945, Konstitusi Republik Indonesia Serikat (RIS) 1949, UUDS 1950 sampai kemudian kembali pada UUD 1945, mekanisme penyelesaian sengketa kewenangan antar lembaga negara belum diadopsi sebagai sebuah mekanisme formil yang memiliki landasan hukum. Di negara lain, kewenangan demikian sudah lama dipraktikkan dalam sistem ketatanegaraannya. Di Korea Selatan misalnya, praktik ketatanegaraan Korea Selatan juga mengakomodir mekanisme penyelesaian SKLN dalam konstitusinya sebagaimana diatur dalam Pasal 111 ayat (1) Konstitusi Korea Selatan Tahun 1987. ${ }^{4}$ Melalui kewenangan tersebut, MK Korea Selatan mendefinisikan batas-batas kewenangan yang diberikan kepada masing-masing instansi (each agency). ${ }^{5}$

Dalam konteks Indonesia, diadopsinya penyelesaian sengketa kewenangan lembaga negara lewat jalur peradilan patut disambut baik sebagai sebuah mekanisme formil yang mana setiap putusannya sangat diyakini akan didasarkan pada pertimbangan yuridis. Pengaturan demikian juga dapat dimaknai dalam rangka menegaskan fungsi MK sebagai peradilan konstitusi di samping kewenangan lain seperti menguji UU terhadap UUD ${ }^{6}$ serta dalam rangka menjaga nilai-nilai konstitusi. ${ }^{7}$ Mekanisme penyelesaian sengketa kewenangan lembaga negara lewat jalur yudisial sangat diyakini memiliki nilai kebenaran dan keadilan yang dapat dipertanggungjawabkan secara yuridis mengingat

Pasal 24C ayat (1) UUD NRI Tahun 1945 menyatakan bahwa, "Mahkamah Konstitusi berwenang mengadili pada tingkat pertama dan terakhir yang putusannya bersifat final untuk menguji undang-undang terhadap Undang-Undang Dasar, memutus sengketa kewenangan lembaga negara yang kewenangannya diberikan oleh Undang-Undang Dasar, memutus pembubaran partai politik, dan memutus perselisihan tentang hasil pemilihan umum".

Jimly Asshiddiqie, 2006, Model-Model Pengujian Konstitusional di Berbagai Negara, Cetakan Ketiga, Konstitusi Press, Jakarta, hlm. 125. Kendati ditemukan adanya perbedaan antara istilah konstitusi dan UUD, yaitu bahwa cakupan konstitusi lebih luas dari UUD, namun demikian bahwa selama ini, istilah konstitusi dan UUD sering digunakan untuk arti dan maksud yang sama. Hal ini didasarkan pada sejumlah pendapat ahli hukum, di antaranya pendapat Sri Soemantri yang mengartikan konstitusi sama dengan UUD. Sri Soemantri M, 2006, Prosedur dan Sistem Perubahan Konstitusi, Alumni, Bandung, hlm. 1. Demikian halnya dengan HM. Laica Marzuki, juga menyamakan istilah Konstitusi dengan UUD. HM. Laica Marzuki, "Kesadaran Berkonstitusi dalam Kaitan Konstitusionalisme”, Jurnal Konstitusi, MK RI, Vol. 6, No. 3, September 2009, hlm. 19.

Menurut ketentuan Article 111 (1) (Competence, Appointment) Chapter VI The Counstitutional Court The Constitution of the Republic of Korea Amanded by Oct. 29, 1987, bahwa The Constitutional Court Korea Selatan berwenang untuk mengadili hal-hal berikut: (1) The unconstitutionality of law upon the request of the courts (inkonstitusional UU atas permintaan pengadilan); (2) Impeachment (pemakzulan); (3) Dissolution of a political party (pembubaran partai politik); (4) Disputes about the jurisdictions between State agencies, between State agencies and local governments, and between local governments (Perselisihan tentang yurisdiksi antara lembaga negara, antara lembaga negara dan pemerintah daerah, dan antara pemerintah daerah); dan (5) Petitions relating to the Constitution as prescribed by law (permohonan yang berkaitan dengan konstitusi).

Jibong Lim, "Korean Constitutional Court Standing at the Crossroads: Focusing on Real Cases and Variational Types of Decisions", Loyola of Los Angeles International and Comparative Law Review, Loyola Marymount University and Loyola Law School, Vol. 24 No. 327,2002, hlm. 347. Lihat juga Gavin Healy, "Judicial Activism in the New Constitutional Court of Korea", Colum. J. Asian L, Vol. 14 No. 213 , 2000, hlm. 219.

Harjono, Transformasi Demokrasi, 2009, Sekretariat Jenderal dan Kepaniteraan MK, Jakarta, hlm. 140.

M, Akil Mochtar, Menjaga Konsistensi Aturan Konstitusi: Peran dan Fungsi Mahkamah Konstitusi, Makalah, disampaikan pada Program Pendidikan Reguler Angkatan XLVI, Lembaga Ketahanan Nasional (Lemhanas) Republik Indonesia, Jakarta, 19 Agustus 2011 , hlm. 7. 
prinsip independensi dan netralitas yang melekat pada lembaga peradilan itu sendiri. Hal inilah yang menjadi nilai positif dari mekanisme penyelesaian sengketa lewat jalur peradilan.

Hanya saja dalam praktiknya kemudian, ternyata pengaturan kewenangan penyelesaian sengketa kewenangan lembaga negara yang diletakkan di bawah ranah kewenangan MK tidak secara otomatis mampu menjawab beragam kebuntuan atas persoalan ketatanegaraan yang ada, khususnya terkait dengan sengketa kewenangan lembaga negara. Pengaturan yang ada saat ini masih menyisakan sejumlah problem dan kerumitan tersendiri dalam mengaplikasikan proses penyelesaian sengketa kewenangan lembaga negara terhadap kasus konkret.

Dikaji dari seluruh substansi yang terkandung dalam UUD NRI Tahun $1945,{ }^{8}$ khususnya Pasal 24C ayat (1) sebagai landasan konstitusional bagi MK dalam menyelesaikan perkara sengketa kewenangan lembaga negara, tidak sedikitpun ditemukan rumusan terkait dengan apa sesungguhnya yang dimaksud dengan istilah lembaga negara. Ketiadaan definisi lembaga negara dalam UUD NRI Tahun 1945 melahirkan problem tersendiri terkait dengan lembaga-lembaga negara mana saja sebenarnya yang memiliki kedudukan hukum (legal standing) dalam perkara sengketa kewenangan lembaga negara.

Selain itu, problem berikutnya adalah terkait dengan ketiadaan makna frasa "yang kewenangannya diberikan oleh Undang-Undang Dasar" sebagaimana disebutkan dalam Pasal 24C ayat (1) UUD NRI Tahun 1945. Apakah pengertian kewenangan yang diberikan UUD adalah merupakan kewenangan yang secara eksplisit disebutkan dalam UUD atau termasuk kewenangan yang secara implisit, juga tidak ditemukan rumusan secara pasti. Hal demikian tentunya akan sangat rentan melahirkan problem hukum dalam rangka menyelesaikan perkara sengketa kewenangan lembaga negara di MK.

Setidaknya, dua hal dimaksud menjadi problem yang sangat berpotensi menimbulkan terganggunya penanganan perkara sengketa kewenangan lembaga negara. Sehubungan dengan itu, maka tulisan ini dimaksudkan dapat memberikan dan menambah cakrawala pemahaman yang lebih komprehensif atau setidaknya menambah referensi ilmiah terkait dengan apa sesungguhnya yang menjadi problematika dalam penyelesaian sengketa kewenangan lembaga negara di MK. Melalui penelitian ini, nantinya diharapkan agar praktik penyelesaian sengketa kewenangan lembaga negara di MK dapat dijalankan lebih efektif dan efisien, sehingga keberadaan MK sebagai salah satu lembaga pelaksana kekuasaan kehakiman dapat berkontribusi maksimal dalam rangka menyelesaikan kasus-kasus berdimensi ketatanegaraan di tanah air.

\section{B. Pembahasan}

\section{Definisi Istilah Lembaga Negara}

Sebagaimana telah disinggung sepintas dalam bagian awal tulisan ini, bahwa sampai saat ini belum ditemukan satu rumusan baku dalam UUD NRI Tahun 1945 terkait apa sesungguhnya yang dimaksud dengan istilah lembaga negara. Bahkan penggunaan istilah itu sendiri pun masih tergolong beragam. Berdasarkan kepustakaan Belanda, istilah "lembaga negara" dikenal dengan "staat organen", sedangkan di Inggris disebut dengan istilah "political institution" dan di Indonesia menggunakan istilah "lembaga negara, badan negara atau organ negara". ${ }^{9}$ Oleh sebab itu, maka definisi lembaga negara yang sering dikemukakan selama ini juga masih sangat beragam dan belum

\footnotetext{
Dari seluruh ketentuan dalam UUD NRI Tahun 1945, istilah lembaga negara hanya ditemukan dalam dua pasal berbeda, yaitu Pasal $24 \mathrm{C}$ ayat (1) dan Pasal II Aturan Peralihan. Adapun penggunaan istilah lembaga negara pada kedua pasal dimaksud diletakkan bukan dalam rangka menyebutkan nama-nama lembaga negara atau dengan kata lain bukan ditujukan dalam rangka menyebutkan lembaga-lembaga yang termasuk kategori lembaga negara. Bentuk dan pola pengaturan demikian pada akhirnya menimbulkan persoalan tersendiri yang tidak kalah rumitnya dengan persoalan-persoalan lain dalam bidang ketatanegaraan. Ketidakjelasan batasan definisi dari istilah lembaga negara dalam UUD NRI Tahun 1945 melahirkan situasi yang penuh dengan multitafsir terkait apa sesungguhnya makna dan definisi dari istilah lembaga negara. Firmansyah Arifin, et al., 2005, Lembaga Negara dan Sengketa Kewenangan Antarlembaga Negara, Cetakan Pertama, Edisi Pertama, KRHN Bekerjasama dengan MKRI, Jakarta, hlm. 29.
} 
dapat diakhiri pada satu kesimpulan secara pasti.

Menurut Kamus Besar Bahasa Indonesia (KBBI) versi offline 1.3, istilah "lembaga" memiliki sejumlah pengertian, di antaranya: (1) asal mula (yang akan menjadi sesuatu), (2) benttuk (rupa, wujud) yang asli, (3) acuan, ikatan, (4) badan (organisasi) yang tujuannya melakukan suatu penyelidikan keilmuan atau melakukan suatu usaha, (5) kepala suku, dan (6) pola perilaku manusia yang mapan. Sedangkan menurut data Wikipedia, ${ }^{10}$ yang dimaksud dengan lembaga negara adalah lembaga pemerintahan atau "Civilizated Organization" dimana lembaga tersebut dibuat oleh negara, dari negara, dan untuk negara di mana bertujuan untuk membangun negara itu sendiri. Lebih lanjut, dikemukakan bahwa lembaga negara terbagi dalam beberapa macam yang pada prinsipnya memiliki tugas umum sebagai berikut: menjaga kestabilan atau stabilitas keamanan, politik, hukum, hak asasi manusia dan budaya; menciptakan suatu lingkungan yang kondusif, aman, tenteram dan harmonis; menjadi badan penghubung antara negara dengan rakyatnya; menjadi sumber inspirasi atau inspirator bagi seluruh rakyatnya; memberantas tindak pidana korupsi, kolusi maupun nepotisme serta berbagai bentuk kejahatan lainnya; dan membantu menjalankan roda pemerintahan negara.

Secara sederhana, istilah organ negara atau lembaga negara dapat dibedakan dari perkataan organ atau lembaga swasta, lembaga masyarakat atau yang biasa disebut dengan ornop (organisasi non pemerintah) atau Non Government Organization (NGO) atau Non Governmental Organizations (NGO's). Oleh sebab itu, lembaga apa saja yang dibentuk bukan sebagai lembaga masyarakat dapat disebut sebagai lembaga negara yang dapat berada dalam ranah eksekutif, legislative, yudikatif maupun yang bersifat campuran. ${ }^{11}$ Sejumlah definisi di atas hanyalah merupakan pengertian lembaga atau lembaga negara secara umum. Artinya belum masuk dalam ruang lingkup yang lebih spesifik terkait dengan pengertian lembaga negara dalam perspektif ketatanegaraan, baik dari segi fungsi, kewenangan, tanggung jawab maupun mekanisme pengawasannya. Oleh sebab itu, guna memberikan pemahaman yang lebih komprehensif mengenai definisi lembaga negara, berikut akan diuraikan sejumlah definisinya.

Menurut pandangan Dewi Oktaviani, et al., ${ }^{12}$ yang dimaksud dengan lembaga negara adalah lembaga pemerintahan yang berkedudukan di pusat yang tugas, fungsi dan kewenangannya secara tegas diatur dalam UUD NRI Tahun 1945. Lembaga negara atau yang dapat juga disebut dengan istilah alat-alat kelengkapan negara dapat dimaknai sebagai institusi-institusi yang dibentuk dalam rangka menjalankan dan melaksanakan fungsifungsi negara. ${ }^{13}$ Pengertian dalam konteks kekinian tentang lembaga negara adalah lembaga negara yang kewenangannya diberikan oleh UUD $1945 .{ }^{14}$

Menurut Penulis, secara sederhana bahwa yang dimaksud dengan lembaga negara adalah alat kelengkapan negara atau istilah lain yang dipergunakan untuk itu yang berfungsi untuk melaksanakan dan menjalankan tugas pokok kekuasaan negara. Istilah lembaga negara juga sering disebut dengan istilah lain seperti lembaga pemerintahan, penyelenggara negara atau sejumlah istilah lainnya. Antara lembaga negara dengan lembaga pemerintahan pada hakikatnya masih dimungkinkan dibedakan secara lebih spesifik. Adapun yang dimaksud dengan lembaga pemerintahan pada dasarnya mengacu pada istilah "pemerintah". Sedangkan pengertian pemerintah

\footnotetext{
Wikipedia, "Lembaga Negara", https://id.wikipedia.org/wiki/Lembaga_Negara, diakses 20 November 2015.

Jimly Asshiddiqie, 2006, Perkembangan dan Konsolidasi Lembaga_Negara Pasca Reformasi, Cetakan Kedua, Sekretariat Jenderal dan Kepaniteraan MKRI, Jakarta, hlm. 30-31.

12 Dewi Oktaviani, et al., 2010, Penataan Mekanisme Hubungan Antar Lembaga Negara, Pusat Kajian Kinerja Kelembagaan LAN, Jakarta, hlm. 13.

Muh. Kusnardi dan Bintan Saragih, 2000, Ilmu Negara, Edisi Revisi, Gaya Media Pratama, Jakarta, hlm. 241.

14 Pengertian ini didasarkan pada bunyi Pasal 1 angka 5 Peraturan MK Nomor 08/PMK/2006 tentang Pedoman Beracara dalam Sengketa Kewenangan Konstitusional Lembaga Negara.
} 
dalam arti sempit adalah pelaksana kekuasaan eksekutif. Dengan demikian, maka lembaga pemerintahan dapat dipahami sebagai lembaga yang menjalankan fungsi kekuasaan eksekutif. Sementara lembaga negara merujuk pada definisi yang lebih luas, yaitu termasuk di dalamnya kekuasaan eksekutif, legislative dan yudikatif.

Ada juga yang membedakan lembaga negara berdasarkan dasar hukum pembentukannya. Melalui jalur ini, maka akan dapat dilihat lembaga negara yang dibentuk berdasarkan UUD NRI Tahun 1945, yang dibentuk berdasarkan undang-undang, berdasarkan peraturan maupun keputusan presiden. Dalam hal proses pemilahan lembaga negara didasarkan pada produk hukum yang menaungi pembentukannya, maka muncullah istilah lembaga negara yang bersifat utama atau primer dan lembaga yang bersifat sekunder atau penunjang (auxiliary) atau sering juga disebut sebagai lembaga negara bantu.

Lain halnya bila kemudian suatu pandangan didasarkan pada poros utama kekuasaan negara. Melalui pandangan ini, akan muncul pemilahan lembaga negara yang didasarkan pada ranah kekuasaan eksekutif, legislatif, dan yudikatif. Dalam bidang kekuasaan eksekutif, terdapat presiden, wakil presiden dan para pembantunya atau kabinetnya. Sementara dalam bidang kekuasaan legislative, terdapat MPR, DPR dan DPD. Untuk bidang kekuasaan yudikatif, terdapat lembaga negara seperti MA, MK dan KY. Terlepas dari adanya perbedaan definisi maupun penggunaan istilah lembaga negara, pada prinsipnya terdapat suatu titik simpul yang sama terkait dengan makna dari istilah lembaga negara itu sendiri, yaitu lembaga yang menjalankan atau yang berfungsi menjalankan tugas-tugas pemerintahan. Dalam hal ini, lembaga negara dipandang tanpa membedakan dasar hukum pembentukannya, fungsi, tugas serta kewenangannya.

\section{Lembaga yang Disebutkan dan Diatur Kewenangannya dalam UUD NRI Tahun 1945}

Menurut Jimly Asshiddiqie dalam salah satu tulisannya yang berjudul "Lembaga-Lembaga Negara, Organ Konstitusional Menurut UUD 1945 " menjelaskan bahwa dalam ketentuan UUD 1945, terdapat lebih dari 35 subjek jabatan atau subjek hukum kelembagaan yang dapat dikaitkan dengan pengertian lembaga atau organ negara dalam arti yang luas. ${ }^{15}$ Adapun subjek jabatan atau subjek hukum kelembagaan yang dapat dikaitkan dengan pengertian lembaga atau organ negara adalah sebagai berikut: Presiden; ${ }^{16}$ Wakil Presiden; ${ }^{17}$ Dewan Pertimbangan Presiden (Wantimpres); ${ }^{18}$ Kementerian Negara; ${ }^{19}$ Menteri Luar Negeri; ${ }^{20}$ Menteri Dalam Negeri; ${ }^{21}$ Menteri Pertahanan; ${ }^{22}$ Duta, ${ }^{23}$ Konsul; ${ }^{24}$ Pemerintahan Daerah Provinsi; ${ }^{25}$ Gubernur/Kepala Pemerintah Daerah Provinsi; ${ }^{26}$ DPRD Provinsi; ${ }^{27}$ Pemerintahan Daerah Kabupten; ${ }^{28}$ Bupati/Kepala Pemerintah Daerah Kabupaten; ${ }^{29}$ DPRD Kabupaten; ${ }^{30}$ Pemerintahan Daerah Kota; ${ }^{31}$

\footnotetext{
15 Jimly Asshiddiqie, "Lembaga-Lembaga Negara, Organ Konstitusional Menurut UUD 1945", http://www.jimly.com/makalah/namafile/50/ ORGAN-ORGAN_KONSTITUSI.doc, diakses 04 April 2015.

16 Pasal-pasal yang berkaitan dengan kekuasaan presiden dapat dilihat pada Pasal 4, 5, 6, 7, 8, 9, 10, 11, 12, 13, 14, 15, dan Pasal 16 UUD NRI Tahun 1945.

Pasal 4 ayat (2), Pasal 6, 6A, Pasal 7, 7A, 7B, 7C, Pasal 8, dan Pasal 9 UUD NRI Tahun 1945.

18 Ketentuan tentang pembentukan Dewan Pertimbangan Presiden diatur dalam Pasal 16 UUD NRI Tahun 1945. Lembaga ini disingkat dengan istilah Wantimpres dan terkait tugas dan tanggungjawabnya adalah bertugas memberi nasihat dan pertimbangan kepada Presiden. Lihat ketentuan dalam Pasal 17 ayat (1), (2), (3), dan (4) UUD NRI Tahun 1945. 
Walikota/Kepala Pemerintah Daerah Kota; ${ }^{32}$ DPRD Kota. $^{33}$

Kemudian ada juga MPR; $;^{34} \mathrm{DPR} ; ;^{35} \mathrm{DPD} ;{ }^{36}$ Komisi pemilihan umum yang bersifat nasional, tetap dan mandiri, yang diatur lebih lanjut dengan UU; ${ }^{37}$ Bank sentral yang susunan, kedudukan, kewenangan, tanggung jawab, dan independensinya diatur lebih lanjut dengan UU; ${ }^{38} \mathrm{BPK} ;{ }^{39} \mathrm{MA} ;{ }^{40}$ $\mathrm{MK}^{41} ; \mathrm{KY} ;{ }^{42} \mathrm{TNI}^{43}$ dan Polri; ${ }^{44} \mathrm{AD} ;{ }^{45} \mathrm{AL} ;{ }^{46} \mathrm{AU} ;{ }^{47}$ Satuan pemerintahan daerah yang bersifat khusus atau istimewa; ${ }^{48}$ Badan-badan lain yang fungsinya berkaitan dengan kekuasaan kehakiman, ${ }^{49}$ seperti Kejaksaan Agung, Komisi Pemberantasan Tindak Pidana Korupsi, Komisi Nasional Hak Asasi Manusia, dan sebagainya. Terakhir adalah Kesatuan Masyarakat Hukum Adat ${ }^{50}$. Point terakhir ini sebenarnya kurang tepat disebut sebagai salah satu lembaga atau organ negara karena masyarakat hukum adat hanya merupakan kumpulan yang membentuk kesatuan dalam perspektif adat istiadat yang berlaku di suatu daerah dan keberadaannya mendapat pengakuan dari pemerintah.

Dari semua lembaga negara sebagaimana disebutkan di atas, lembaga-lembaga negara yang disebutkan dan diatur kewenangannya secara tegas dalam UUD NRI Tahun 1945 adalah sebagai berikut:

1. Majelis Permusyawaratan Rakyat (MPR)

Adapun yang menjadi kewenangan MPR sebagaimana diatur dalam
UUD NRI Tahun 1945 adalah sebagai berikut: mengubah dan menetapkan UUD; melantik Presiden dan/atau Wakil Presiden hasil pemilihan umum; memutuskan usul DPR untuk memberhentikan Presiden dan/atau Wakil Presiden dalam masa jabatannya, setelah MK memutuskan bahwa Presiden dan/atau Wakil Presiden terbukti melakukan pelanggaran hukum berupa pengkhianatan terhadap negara, korupsi, penyuapan, tindak pidana berat lainnya, atau perbuatan tercela dan/atau terbukti bahwa Presiden dan/atau Wakil Presiden tidak lagi memenuhi syarat sebagai Presiden dan/atau Wakil Presiden; melantik Wakil Presiden menjadi Presiden apabila Presiden mangkat, berhenti, diberhentikan, atau tidak dapat melakukan kewajibannya dalam masa jabatannya; memilih Wakil Presiden dari 2 (dua) calon yang diusulkan oleh Presiden apabila terjadi kekosongan jabatan Wakil Presiden dalam masa jabatannya; dan memilih Presiden dan Wakil Presiden apabila keduanya mangkat, berhenti, diberhentikan, atau tidak dapat melakukan kewajibannya dalam masa jabatannya secara bersamaan, dari 2 (dua) pasangan calon presiden dan wakil presiden yang diusulkan oleh partai politik atau gabungan partai politik yang pasangan calon Presiden dan Wakil Presidennya meraih suara terbanyak pertama dan kedua dalam pemilihan umum

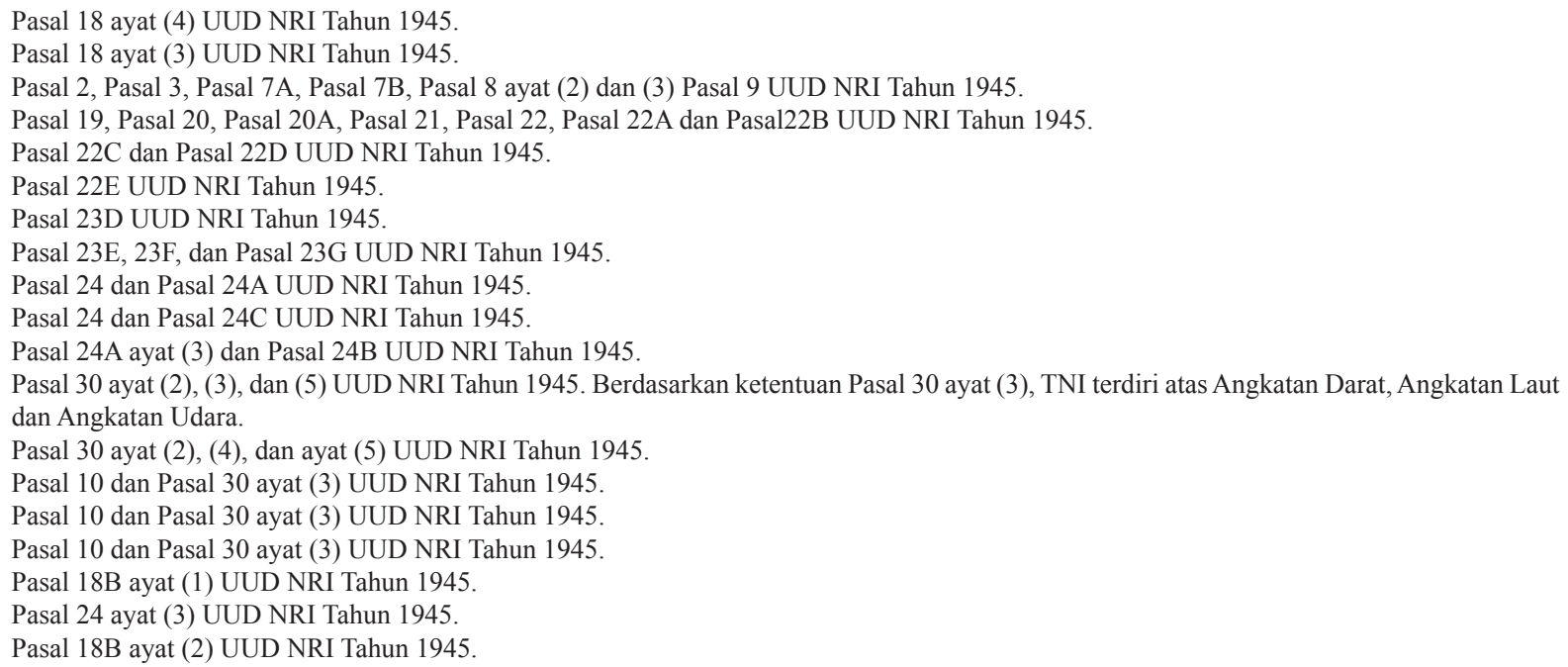


sebelumnya, sampai berakhir masa jabatannya. ${ }^{51}$

2. Dewan Perwakilan Rakyat (DPR)

DPR memiliki tugas, kewenangan dan hak konstitusional sebagai berikut; memegang kekuasaan membentuk UU; mengajukan usul RUU; menjalankan fungsi legislasi, anggaran dan pengawasan; memberikan persetujuan atau tidak memberikan persetujuan terhadap peraturan pemerintah pengganti undang-undang yang diajukan oleh Presiden untuk menjadi UU; menerima RUU yang diajukan oleh DPD berkaitan dengan otonomi daerah, hubungan pusat dan daerah, pembentukan dan pemekaran serta penggabungan daerah, pengelolaan sumber daya alam (SDA) dan sumber daya ekonomi lainnya, serta yang berkaitan dengan perimbangan keuangan pusat dan daerah; membahas RUU bersama Presiden dan DPD sebelum diambil persetujuan bersama antara DPR dan Presiden; membahas RUU yang diajukan oleh Presiden atau DPR yang berkaitan dengan otonomi daerah, hubungan pusat dan daerah, pembentukan dan pemekaran serta penggabungan daerah, pengelolaan SDA dan sumber daya ekonomi lainnya, serta perimbangan keuangan pusat dan daerah, dengan mengikutsertakan DPD sebelum diambil persetujuan bersama antara DPR dan Presiden; memperhatikan pertimbangan DPD atas RUU tentang APBN dan RUU yang berkaitan dengan pajak, pendidikan, dan agama; membahas bersama Presiden dengan memperhatikan pertimbangan DPD dan memberikan persetujuan atas RUU tentang APBN yang diajukan oleh Presiden; melakukan pengawasan terhadap pelaksanaan UU dan APBN; membahas dan menindaklanjuti hasil pengawasan yang disampaikan oleh DPD terhadap pelaksanaan UU mengenai otonomi daerah, pembentukan, pemekaran, dan penggabungan daerah, hubungan pusat dan daerah, pengelolaan SDA dan sumber daya ekonomi lainnya, pelaksanaan APBN, pajak, pendidikan, dan agama; memberikan persetujuan kepada Presiden untuk menyatakan perang, membuat perdamaian dan perjanjian dengan negara lain, serta membuat perjanjian internasional lainnya; memberikan pertimbangan kepada Presiden dalam pemberian amnesti dan abolisi; memberikan pertimbangan kepada Presiden dalam hal mengangkat duta besar dan menerima penempatan duta besar negara lain; memilih anggota BPK dengan memperhatikan pertimbangan DPD; membahas dan menindaklanjuti hasil pemeriksaan atas pengelolaan dan tanggung jawab keuangan negara yang disampaikan oleh BPK; memberikan persetujuan kepada Presiden atas pengangkatan dan pemberhentian anggota $\mathrm{KY}$; memberikan persetujuan calon hakim agung yang diusulkan KY untuk ditetapkan sebagai hakim agung oleh Presiden; memilih 3 (tiga) orang hakim konstitusi dan mengajukannya kepada Presiden untuk diresmikan dengan keputusan Presiden; dan memiliki hak interpelasi, hak angket, dan hak menyatakan pendapat serta hak imunitas.

3. Presiden

Menurut UUD 1945, khususnya setelah amandemen, presiden memiliki sejumlah kewenangan konstitusional, diantaranya: mengajukan RUU kepada DPR dan menetapkan peraturan pemerintah untuk menjalankan UU sebagaimana mestinya: ${ }^{52}$ memegang jabatan selama lima tahun dan sesudahnya dapat dipilih kembali dalam jabatan yang sama hanya untuk satu kali masa jabatan; ${ }^{53}$ memegang kekuasaan yang tertinggi atas $\mathrm{AD}, \mathrm{AL}$ dan $\mathrm{AU} ;{ }^{54}$ dengan persetujuan DPR menyatakan perang,

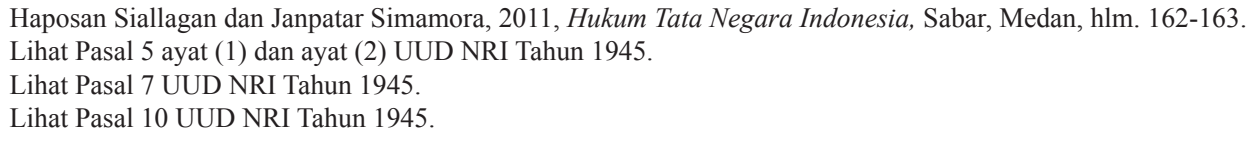


membuat perdamaian dan perjanjian dengan negara lain; ${ }^{55}$ membuat perjanjian internasional lainnya yang menimbulkan akibat yang luas dan mendasar bagi kehidupan rakyat yang terkait dengan beban keuangan negara, dan/atau mengharuskan perubahan atau pembentukan UU dengan terlebih dahulu mendapatkan persetujuan DPR; ${ }^{56}$ menyatakan keadaan bahaya yang mana syarat-syaratnya serta akibatnya ditetapkan dengan $\mathrm{UU} ;{ }^{57}$ mengangkat duta dan konsul serta menerima penenpatan duta negara lain dengan memperhatikan pertimbangan DPR $^{58}$; memberikan grasi dan rehabilitasi dengan pertimbangan MA:59 memberikan amnesti dan abolisi dengan pertimbangan DPR; ${ }^{60}$ memberi gelar, tanda jasa dan lainlain tanda kehormatan yang diatur dengan UU; ${ }^{61}$ membentuk suatu dewan pertimbangan yang bertugas memberikan nasihat dan pertimbangan kepada presiden, yang selanjutnya diatur dalam UU; ${ }^{62}$ mengangkat dan memberhentikan menteri-menteri; ${ }^{63}$ mengesahkan RUU yang telah disetujui bersama antara DPR dan presiden menjadi UU; ${ }^{64}$ mengajukan RUU tentang APBN untuk selanjutnya dibahas bersama dengan DPR dengan memperhatikan pertimbangan DPD;65 meresmikan keanggotaan BPK yang telah dipilih oleh DPR; $;{ }^{66}$ menetapkan hakim agung yang sebelumnya diusulkan oleh KY dan telah mendapat persetujuan DPR; ${ }^{67}$ mengangkat dan memberhentikan anggota KY dengan persetujuan $\mathrm{DPR}^{68}$; dan menetapkan hakim konstitusi yang diajukan masing-masing tiga orang oleh MA, tiga orang oleh DPR dan tiga orang oleh presiden ${ }^{69}$.

4. Wakil Presiden

Memiliki tugas dan kewenangan membantupresiden dalam menjalankan kewenangannya dan mengantikan kedudukan presiden dalam hal presiden mangkat, berhenti, diberhentikan atau tidak dapat menjalankan kewajibannya dalam masa jabatannya.

5. Menteri-Menteri

Memiliki tugas dan kewenangan konstitusional membantu presiden, membidangi urusan tertentu dalam pemerintahan. Khusus terhadap Menteri Luar Negeri, Menteri Dalam Negeri, dan Menteri Pertahanan secara bersama-sama melaksanakan tugas kepresidenan dalam hal Presiden dan Wakil Presiden mangkat, berhenti, diberhentikan, atau tidak dapat melakukan kewajibannya dalam masa jabatannya secara bersamaan.

6. Dewan Pertimbangan Presiden (Wantimpres)

Memiliki tugas dan kewenangan konstitusional dalam memberikan nasihat dan pertimbangan kepada presiden.

7. Pemerintah Daerah (Gubernur, Bupati dan Walikota)

Memiliki kewenangan yang diatur dalam UUD sebagai berikut: mengatur dan mengurus sendiri urusan pemerintahan menurut asas otonomi dan tugas pembantuan; menjalankan otonomi seluas-luasnya, kecuali urusan pemerintahan yang oleh UU ditentukan sebagai urusan pemerintah pusat; dan menetapkan peraturan daerah dan peraturan-peraturan lain

\footnotetext{
Lihat Pasal 11 ayat (1) UUD NRI Tahun 1945.

Lihat Pasal 11 ayat (2) UUD NRI Tahun 1945.

Lihat Pasal 12 UUD NRI Tahun 1945.

Lihat Pasal 13 UUD NRI Tahun 1945.

Lihat Pasal 14 ayat (1) UUD NRI Tahun 1945.

Lihat Pasal 14 ayat (2) UUD NRI Tahun 1945.

Lihat Pasal 15 UUD NRI Tahun 1945.

Lihat Pasal 16 UUD NRI Tahun 1945.

Lihat Pasal 17 ayat (2) UUD NRI Tahun 1945.

Lihat Pasal 20 ayat (4) UUD NRI Tahun 1945.

Lihat Pasal 23 ayat (2) UUD NRI Tahun 1945.

Lihat Pasal 23F ayat (1) UUD NRI Tahun 1945

Lihat Pasal 24A ayat (3) UUD NRI Tahun 1945.

Lihat Pasal 24B ayat (3) UUD NRI Tahun 1945.

Lihat Pasal 24C ayat (3) UUD NRI Tahun 1945.
} 
untuk melaksanakan otonomi dan tugas pembantuan.

8. Mahkamah Agung (MA)

Adapun yang menjadi kewenangan MA menurut UUD NRI Tahun 1934 adalah: mengadili pada tingkat kasasi; menguji peraturan perundangundangan di bawah UU terhadap UU; mengajukan 3 orang hakim konstitusi; memberikan pertimbangan kepada presiden dalam hal presiden memberi grasi dan rehabilitasi; dan wewenang lainnya yang diberikan oleh UU;

9. Mahkamah Konstitusi (MK)

Adapun yang menjadi kewenangan konstitusional MK adalah sebagai berikut: menguji UU terhadap UUD; memutus sengketa kewenangan lembaga negara yang kewenangannya diberikan oleh UUD; memutus pembubaran partai politik; memutus perselisihan tentang hasil pemilihan umum; dan memberikan putusan atas pendapat DPR bahwa Presiden dan/ atau Wakil Presiden diduga telah melakukan pelanggaran hukum berupa pengkhianatan terhadap negara, korupsi, penyuapan, tindak pidana berat lainnya atau perbuatan tercela, dan/atau tidak lagi memenuhi syarat sebagai Presiden dan/atau Wakil Presiden.

10. Komisi Yudisial (KY)

Memiliki kewenangan konstitusional dalam mengusulkan pengangkatan hakim agung dan mempunyai wewenang lain dalam rangka menjaga dan menegakkan kehormatan, keluruhan martabat serta perilaku hakim.

11. Badan Pemeriksa Keuangan (BPK)

Memiliki kewenangan konstitusional dalam memeriksa pengelolaan dan tanggung jawab keuangan negara dan menyerahkan hasil pemeriksaannya kepada DPR, DPD dan DPRD.

12. Komisi Pemilihan Umum (KPU)

Istilah lembaga KPU sebenarnya tidak disebutkan secara eksplisit dalam UUD NRI Tahun 1945. Keberadaan KPU hanya tercermin dalam ketentuan yang berbunyi "Pemilihan umum diselenggarakan oleh suatu komisi pemilihan umum yang bersifat nasional, tetap dan mandiri”. Jadi kewenangannya adalah menyelenggarakan pemilihan umum.

13. Tentara Nasional Indonesia (TNI)

TNI terdiri dari Angkatan Darat, Angkatan Laut dan Angkatan Udara berdasarkan UUD NRI Tahun 1945 memiliki tugas dan kewenangan adalah bersama-sama dengan Polri bertugas sebagai kekuatan utama dalam usaha pertahanan dan keamanan negara, mempertahankan, melindungi dan mempertahankan keutuhan dan kedaulatan negara.

14. Kepolisian Negara Republik Indonesia (Polri)

Kewenangan konstitusional Polri adalah bersama-sama dengan TNI bertugas sebagai kekuatan utama dalam usaha pertahanan dan keamanan negara, sebagai alat negara menjaga keamanan dan ketertiban masyarakat, melindungi, mengayomi, melayani masyarakat dan menegakkan hukum.

Selain daripada lembaga-lembaga yang kewenangannya disebutkan atau diatur dalam UUD NRI Tahun 1945, masih terdapat sejumlah lembagalembaga negara yang keberadaannya hanya disebutkan dalam UUD, namun masalah pengaturan kewenangannya didelegasikan untuk diatur dalam tingkatan UU. Salah satu contoh lembaga negara yang disinggung dalam UUD dan pengaturan kewenangannya dilakukan di tingkatan UU adalah Bank Indonesia. Menurut ketentuan Pasal 23D UUD NRI Tahun 1945, negara memiliki suatu bank sentral yang susunan, kedudukan, kewenangan dan tanggung jawab serta independensinya diatur dengan UU. Sekalipun tidak ditemukan rumusan yang pasti terkait nomenklatur Bank Indonesia dalam pasal tersebut, namun dapat dipahami bahwa yang dimaksudkan sebagai bank sentral dalam pasal tersebut adalah Bank Indonesia.

Ada juga sejumlah lembaga yang hanya disebutkan bukan dalam rangka mempertegas keberadaan dan kedudukannya sebagai lembaga negara, melainkan hanya karena proses pengangkatannya. Lembaga-lembaga seperti itu di antaranya adalah duta dan konsul yang hanya disinggung terkait dengan kewenangan presiden dalam 
mengangkatnya dengan persetujuan DPR. Di sisi lain, lembaga-lembaga negara yang sejak dahulu kala sudah mendapat pengakuan sebagai bagian dari lembaga utama negara seperti Kejaksaan Republik Indonesia justru tidak disebutkan sama sekali dalam UUD. Demikian juga dengan KPK yang baru dikenal sejak era reformasi dan tidak kalah urgensinya sebagai salah satu lembaga dalam sistem ketatanegaraan Indonesia juga tidak mendapatkan pengaturan kewenangan secara konstitusional. ${ }^{70}$

3. Batasan Lembaga Negara yang Memiliki Kedudukan Hukum dalam Perkara Sengketa Kewenangan Lembaga Negara

Sebagaimana dikemukakan sebelumnya bahwa menurut ketentuan Pasal 24C ayat (1) UUD NRI Tahun 1945, salah satu kewenangan MK adalah memutus sengketa kewenangan lembaga negara yang kewenangannya diberikan oleh UUD. Berpijak dari ketentuan dimaksud, maka dapat dipahami bahwa setidaknya terdapat dua unsur pokok terkait definisi lembaga negara yang memiliki kedudukan hukum (legal standing) dalam perkara sengketa kewenangan lembaga negara. Kedua unsur pokok dimaksud adalah pertama, lembaga negara itu disebutkan dalam UUD, kedua, kewenangan lembaga negara dimaksud diberikan oleh UUD. Unsur pertama memang tidak disebutkan secara eksplisit dalam ketentuan dimaksud. Namun didasarkan pada ketentuan bahwa lembaga negara yang dapat memiliki kedudukan hukum (legal standing) adalah lembaga negara yang kewenangannya diberikan oleh UUD, maka secara otomatis bahwa lembaga negara dimaksud harus disebutkan dalam UUD.

Hal ini bertolak pada pemikiran logis bahwa tidak mungkin sebuah lembaga negara diatur kewenangannya dalam UUD tanpa menyebutkan nama lembaga negara tersebut. Dengan demikian, maka dapat disimpulkan bahwa kedua unsur dimaksud merupakan syarat mutlak yang berlaku secara kumulatif. Satu saja di antara kedua unsur dimaksud tidak terpenuhi, maka dapat diartikan bahwa lembaga negara tersebut tidak memiliki kedudukan hukum atau legal standing, baik sebagai pemohon maupun termohon dalam perkara sengketa kewenangan lembaga negara yang merupakan ranah kewenangan MK.

Selanjutnya, menurut ketentuan Pasal 61 ayat (1) UU No. 24 Tahun 2003 Tentang Mahkamah Konstitusi sebagaimana telah diubah menjadi UU No. 8 Tahun 2011 Tentang Perubahan Atas UU No. 24 Tahun 2003 Tentang Mahkamah Konstitusi, bahwa yang dapat menjadi pemohon dalam sengketa kewenangan lembaga negara adalah lembaga negara yang kewenangannya diberikan oleh UUD NRI Tahun 1945 yang mempunyai kepentingan langsung terhadap kewenangan yang dipersengketakan. Selain itu, dalam ayat (2) pasal yang sama ditegaskan bahwa pemohon wajib menguraikan dengan jelas dalam permohonannya tentang kepentingan langsung pemohon dan menguraikan kewenangan yang dipersengketakan serta menyebutkan dengan jelas lembaga negara mana yang menjadi termohon.

Kemudian dalam rangka memperlancar pelaksanaan tugas dan kewenangan dalam memutus perkara sengketa kewenangan lembaga negara, MK mengeluarkan Peraturan No. 8/PMK/2006 Tentang Pedoman Beracara Dalam Sengketa Kewenangan Konstitusional Lembaga Negara. ${ }^{71}$ Menurut peraturan dimaksud, batasan definisi lembaga negara diletakkan pada pengertian lembaga negara yang kewenangannya diberikan oleh UUD. Ketentuan dimaksud dipertegas melalui Pasal 2 ayat (1) dengan menyebutkan nama-nama lembaga negara yang dapat menjadi pemohon maupun termohon

70 Di luar itu, masih ditemukan juga sederet lembaga-lembaga lainnya yang sama sekali tidak disinggung dalam UUD, baik masalah istilah atau penamaannya maupun kewenangannya. Lembaga-lembaga semacam ini diatur dalam tingkatan regulasi setingkat UU atau Keputusan Presiden. Umumnya lembaga-lembaga ini menggunakan istilah badan atau komisi atau dewan seperti Komnas HAM, Komisi Penyiaran Indonesia (KPI), Komisi Perlindungan Anak Indonesia (Komnas Anak), Komisi Kejaksaan dan Komisi Kepolisian Nasional (Kompolnas), Dewan Pers serta sejumlah lembaga lainnya.

71 Menurut Pasal 1 angka 6 Peraturan MK Nomor 8/PMK/2006, yang dimaksud dengan kewenangan konstitusional lembaga negara adalah kewenangan yang dapat berupa wewenang/hak dan tugas/kewajiban lembaga negara yang diberikan oleh UUD NRI Tahun 1945. 
dalam perkara sengketa kewenangan konstitusional lembaga negara. Adapun lembaga negara yang dapat menjadi pemohon maupun termohon dalam perkara sengketa kewenangan konstitusional lembaga negara menurut Pasal 2 ayat (1) PMK No. 8/PMK/2006 adalah sebagai berikut: DPR; DPD; MPR; Presiden; BPK; Pemerintah Daerah; dan lembaga negara lainnya yang kewenangannya diberikan oleh UUD NRI Tahun 1945.

Pada ayat (2) pasal yang sama ditegaskan bahwa kewenangan yang dipersengketakan adalah kewenangan lembaga negara yang diberikan atau ditentukan oleh UUD NRI Tahun 1945. Kemudian terkait dengan syarat-syarat sebagai pemohon, dijelaskan lebih lanjut bahwa pemohon adalah lembaga negara yang menganggap kewenangan konstitusionalnya diambil, dikurangi, dihalangi, diabaikan dan atau dirugikan oleh lembaga negara yang lain. Selain itu, pemohon juga harus mempunyai kepentingan langsung terhadap kewenangan yang dipersengketakan. Jadi, sepanjang tidak ditemukan kepentingan langsung, maka sebuah lembaga negara tidak dapat menjadi pemohon dalam sengketa kewenangan lembaga negara. Adapun yang dapat dijadikan termohon adalah lembaga negara yang dianggap telah mengambil, mengurangi, menghalangi atau mengabaikan maupun merugikan pemohon.

Berpijak pada sejumlah ketentuan dimaksud, maka dapat disimpulkan bahwa syarat-syarat lembaga-lembaga negara yang memiliki legal standing sebagai pemohon maupun termohon dalam perkara sengketa kewenangan lembaga negara adalah:

1. lembaga negara yang kewenangannya diberikan atau ditentukan dalam UUD NRI Tahun 1945;

2. lembaga negara dimaksud memiliki kepentingan langsung terhadap kewenangan yang dipersengketakan;

3. bagi pemohon, ada anggapan bahwa kewenangan konstitusionalnya diambil, dikurangi, dihalangi, diabaikan dan atau dirugikan oleh lembaga negara yang lain.

Syarat terakhir tersebut dapat ditafsirkan sebagai adanya hubungan kausal kerugian yang dialami kewenangannya dengan kewenangan yang dilaksanakan oleh lembaga negara lain. ${ }^{72}$ Jika didasarkan pada sejumlah syarat yang disebutkan di atas, dapat dirinci bahwa lembaga negara yang kemungkinan memiliki legal standing dalam perkara sengketa kewenangan lembaga negara adalah MPR, DPR, DPD, Presiden, Wakil Presiden, Menteri-Menteri, Pemerintah Daerah, MA, ${ }^{73} \mathrm{MK}$, KY, BPK, KPU, TNI dan Polri. Lembaga-lembaga inilah yang kewenangannya secara tegas disebutkan maupun diatur dalam UUD NRI Tahun 1945.

Namun kemudian, bila memperhatikan substansi Pasal 67 UU Nomor 24 Tahun 2003 yang menyebutkan bahwa putusan MK mengenai sengketa kewenangan disampaikan kepada DPR, DPD dan Presiden, maka bisa jadi muncul penafsiran lain terkait dengan pemahaman tentang lembaga negara $^{74}$ mana saja yang memiliki legal standing dalam perkara SKLN. Selain itu, jika merujuk pada pemaknaan istilah lembaga negara sebagai lembaga yang menjalankan tugas pokok kekuasaan negara, maka semua lembaga yang disebutkan secara tegas dalam UUD NRI Tahun 1945 tidak secara otomatis memiliki kedudukan hukum dalam perkara sengketa kewenangan lembaga negara. Artinya hanya lembaga yang benar-benar menjalankan tugas pokok kekuasaan negara saja seperti MPR, DPR, DPD, Presiden, MA dan MK saja yang dapat dikualifikasikan memiliki kedudukan hukum atau

\footnotetext{
Maruarar Siahaan, 2006, Hukum Acara Mahkamah Konstitusi Republik Indonesia, Edisi Revisi, MKRI, Jakarta, hlm. 195.

Pada awalnya, MA dikecualikan sebagai lembaga yang tidak dapat menjadi pihak dalam sengketa kewenangan lembaga negara. Ketentuan ini diatur dalam Pasal 65 UU No. 24 Tahun 2004 Tentang Mahkamah Konstitusi. Namun kemudian seiring dengan perubahan UU No 24 Tahun 2003 menjadi UU No. 8 Tahun 2011, maka Pasal 65 tersebut dinyatakan dihapus. Dengan demikian, saat ini MA dimungkinkan menjadi salah satu pihak, baik pemohon maupun termohon dalam perkara sengketa kewenangan lembaga negara.

74 Abdul Muktie Fajar, 2006, Hukum Konstitusi dan Mahkamah Konstitusi, Konstitusi Press, Jakarta, hlm. 184.
} 
legal standing dalam perkara sengketa kewenangan lembaga negara. ${ }^{75}$

\section{Problematika Penyelesaian Sengketa Ke- wenangan Lembaga Negara}

Kendati sudah ditemukan sejumlah regulasi yang mengatur mekanisme penyelesaian sengketa kewenangan lembaga negara oleh MK, baik yang diatur dalam UUD NRI Tahun 1945, maupun peraturan turunan lainnya seperti UU MK dan Peraturan MK, namun demikian bahwa proses penyelesaian perkara dimaksud masih menyisakan problematika tersendiri yang berpotensi menyulitkan pengimplementasiannya dalam kasus konkret. Hal ini kian rumit seiring dengan suburnya pertumbungan dan perkembangan lembaga-lembaga, khususnya sejak era reformasi. Terdapat berbagai lembaga negara dengan pola pengaturan maupun tingkatan landasan hukum yang berbeda-beda. Berdasarkan tingkatan regulasi yang menjadi dasar hukum pembentukannya, ada lembaga-lembaga negara yang dibentuk berdasarkan UUD, ada yang dibentuk berdasarkan UU dan ada pula lembaga yang dibentuk berdasarkan Keputusan Presiden.

Lembaga-lembaga yang yang diatur di luar UUD, umumnya disebut komisi negara atau lembaga negara pembantu (state auxiliary agencies) yang dibentuk berdasarkan UU atau peraturan lainnya. ${ }^{76}$ Secara keseluruhan, keberadaan semua lembaga dimaksud diakui keabsahannya sebagai lembaga yang dibentuk oleh pemerintah, namun tugas dan kedudukannya hanya bersifat penunjang bagi pelaksanaan kekuasaan negara. Dalam hal proses berperkara dalam sengketa kewenangan lembaga negara, tidak semua lembaga negara dimaksud memenuhi unsur sebagai pemohon maupun termohon.

Selain itu, ada juga lembaga negara yang disebutkan dalam UUD, namun kewenangannya hanya disebutkan di tingkatan UU atau atas dasar perintah UUD kewenangannya diatur dalam UU. Bahkan yang lebih rumit kemudian adalah adanya lembaga negara yang sama sekali tidak disebutkan dalam UUD, namun keberadaannya tidak kalah penting atau tidak kalah derajatnya dengan lembaga-lembaga negara yang disebutkan dalam UUD. Sebut saja misalnya Kejaksaan Republik Indonesia yang sama sekali tidak disinggung dalam UUD, namun semua orang mengakui dan bahkan menyadari bahwa keberadaan Kejaksaan Republik Indonesia sama pentingnya dengan keberadaan lembaga peradilan seperti MA maupun MK.

Situasi dan kondisi yang demikian pada akhirnya sangat menyulitkan dalam upaya penyelesaian sengketa kewenangan lembaga negara. Sebagai contoh, bagaimana mekanisme penyelesaian masalah sengketa kewenangan terhadap lembaga yang kewenangannya hanya diatur dalam tingkatan UU seperti Kejaksaan, KPK, KPI, Komnas HAM, KPPU dan lembaga lainnya maupun yang diatur dalam ringkatan Keputusan Presiden. Lembaga mana sesungguhnya yang akan menyelesaikan masalah yang dihadapi oleh lembaga negara tersebut. Kalau kemudian persoalan sengketa kewenangan yang demikian dibawa ke MK, dapat dipastikan bahwa MK tidak akan menerima pengaduan sengketa dimaksud. Pasalnya, kewenangan MK dalam menyelesaikan sengketa kewenangan lembaga negara memiliki rambu pembatas hanya terhadap lembaga negara yang kewenangannya diberikan oleh UUD.

Berdasarkan catatan MK, sejak berdiri sampai dengan tahun 2015, tercatat sudah 25 (dua puluh lima) perkara yang diperiksa terkait dengan perkara sengketa kewenangan lembaga negara dan 24 (dua puluh empat) perkara sudah berhasil diputus oleh MK. Dari seluruh sengketa kewenangan lembaga negara yang ditangani MK selama ini, hanya 1 (satu) perkara yang kemudian dikabulkan. Selebihnya,

\footnotetext{
75 Di sisi lain, keberadaan sejumlah lembaga negara lainnya yang walaupun secara kelembagaan disebutkan atau diatur dalam UUD NRI Tahun 1945 seperti Bank Indonesia, Duta dan konsul, namun karena kewenangannya tidak diatur dalam konstitusi, maka berdasarkan ketentuan yang ada, lembaga-lembaga tersebut dapat diartikan tidak memenuhi syarat baik sebagai pemohon maupun termohon dalam perkara sengketa kewenangan lembaga negara. Penafsiran semacam ini berlaku bila batasan definisi lembaga negara diartikulasikan secara gramatikal.

76 Firmansyah Arifin, et al., Op.cit., hlm. 3.
} 
yaitu 3 (tiga) perkara dinyatakan ditolak, 16 (enam belas) perkara dinyatakan tidak dapat diterima dan 4 (empat) perkara ditarik kembali oleh pemohonnya. ${ }^{77}$ Dilihat dari alur hukum pertimbangan MK yang melatarbelakangi MK sampai pada putusannya, umumnya perkara dinyatakan tidak diterima dikarenakan tidak terpenuhinya syarat dalam sebuah permohonan. Salah satu contoh dapat dilihat dalam perkara dengan Nomor 1/SKLN-X/2012, dimana Menteri sebagai salah satu pihak dalam perkara dimaksud dinyatakan tidak memenuhi syarat subjectum litis karena Menteri dianggap tidak bisa langsung sebagai pemohon. ${ }^{78}$ Bahkan dalam kurun waktu tahun 2003 sampai dengan Juli 2011, tidak ada satupun perkara SKLN yang dikabulkan oleh MK. Dari 13 (tiga belas) perkara yang masuk selama dalam kurun waktu tersebut, masingmasing perkara diputus dengan amar putusan, 2 (dua) perkara ditolak, 8 (delapan) perkara tidak diterima $^{79}$ dan 3 (tiga) perkara ditarik kembali oleh pemohonnya. ${ }^{80}$

Umumnya perkara-perkara sengketa kewenangan lembaga negara di MK berakhir pada persoalan terkait kapasitas masing-masing pihak, apakah dapat dikategorikan sebagai lembaga negara atau tidak. Selain itu, dilihat dari sejumlah putusan sengketa kewenangan lembaga negara selama ini, persoalan apakah kewenangan yang dipersengketakan merupakan kewenangan yang diberikan UUD atau tidak juga merupakan persoalan yang tidak kalah rumitnya dengan persoalan keberadaan masing-masing pihak apakah sebagai lembaga negara atau tidak.

Sehubungan dengan itu, maka dalam rangka mengefektifkan pelaksanaan kewenangan MK dalam memutus sengketa kewenangan lembaga negara, kiranya perlu dilakukan penegasan terkait dua hal, yaitu pertama, penegasan mengenai batasan makna lembaga negara dan kedua, penegasan mengenai batasan lembaga negara yang kewenangannya diberikan oleh UUD. Sepanjang kedua hal dimaksud tidak diselesaikan dan dituntaskan dengan baik, maka sangat diyakini bahwa penyelesaian sengketa kewenangan lembaga negara oleh MK akan tetap menghadapi probematika tersendiri yang pada akhirnya akan sangat mengganggu bagi efektifitas pelaksanaan kewenangan MK di kemudian hari.

Adanya frasa "[...] yang kewenangannya diberikan oleh Undang-Undang Dasar, [...]" dalam Pasal 24C ayat (1) UUD NRI Tahun 1945 jelas ditujukan dalam rangka melakukan pembatasan terhadap lembaga-lembaga yang dapat menjadi para pihak dalam perkara sengketa kewenangan lembaga negara. Oleh sebab itu, sepanjang suatu norma hukum ditujukan dalam rangka melakukan pembatasan, maka diperlukan suatu rumusan yang secara tegas terkait dengan pembatasan dimaksud.

Berbeda halnya jika kemudian ketentuan dimaksud tidak ditujukan sebagai rambu pembatas dalam perkara sengketa kewenangan lembaga negara. Jika memang tidak dimaksudkan untuk membatasi, maka semestinya ketentuan frasa "yang kewenangannya diberikan oleh UUD" sebagaimana tercantum dalam Pasal 24C ayat (1) UUD NRI Tahun 1945 tidak perlu dicantumkan. Dengan demikian, maka seluruh sengketa lembaga negara tanpa membedakan dasar hukum pengaturan kewenangannya dapat diselesaikan di MK. Kalau pada akhirnya, situasi ini diprediksi terlalu membebani kinerja MK, maka sebagai solusinya dapat saja formasi hakim di MK ditambah dari jumlah hakim yang ada saat ini. Selain itu, alternative lain yang kemudian dapat ditempuh adalah dengan membagi kewenangan sengketa

77 Mahkamah Konstitusi, "Rekapitulasi Perkara Sengketa Kewenangan Lembaga Negara", http://www.mahkamahkonstitusi.go.id/index. php? page $=$ web.RekapSKLN, diakses 14 November 2015.

78 Laporan Kinerja Mahkamah Konstitusi Tahun 2012, hlm. 34

79 Salah satu kasus atau perkara sengketa kewenangan lembaga negara yang diputus dengan amar putusan tidak dapat diterima adalah kasus Bupati/Wakil Bupati Depok terhadap KPUD Kota Depok yang diputus melalui putusan MK No. 002/SKLN-IV/2006. Amar putusan MK ketika itu menyatakan bahwa permohonan pemohon tidak dapat diterima (niet ontvankelijk verklaard). MK juga berpendapat bahwa kewenangan KPUD bukanlah kewenangan yang diberikan oleh UUD NRI Tahun 1945. Putusan ini dibacakan pada Sidang Pleno Mahkamah Konstitusi, Rabu, 25 Januari 2006. Periksa lebih lanjut, Laporan Tahunan Mahkamah Konstitusi Tahun 2006, hlm. 49-50.

$80 \quad$ M. Akil Mochtar, Loc.cit. 
lembaga negara di bawah ranah kewenangan MA dan MK. Jadi bisa saja misalnya batasan defenisi lembaga negara dalam perspektif sengketa kewenangan lembaga negara sebagaimana yang ada saat ini tetap dipertahankan, namun kemudian perlu dilakukan pengaturan lanjutan terkait dengan mekanisme penyelesaian sengketa kewenangan lembaga negara yang kewenangannya diatur dalam UU atau peraturan di tingkatan bawahnya dengan menempatkannya di bawah ranah kewenangan MA.

Pola pengaturan yang demikian hampir sama dengan pola pengaturan kewenangan judicial review antara MK dan MA. MK berwenang menguji UU terhadap UUD, sedangkan MA menguji peraturan perundang-undangan di bawah UU terhadap UU. Opsi terakhir ini bisa saja dianggap lebih realistis dalam rangka penyelesaian perkara sengketa kewenangan lembaga negara lewat jalur yudisial, karena dua lembaga negara pelaksana kekuasaan kehakiman (MA dan MK) sama-sama berperan aktif dalam menuntaskan setiap sengketa kewenangan lembaga negara yang ada. Hal ini juga sejalan dengan apa yang dikatakan Montesquieu ${ }^{81}$ bahwa keberadaan lembaga pelaksana kekuasaan kehakiman, lebih independent serta memegang prinsip netralitas.

Namun demikian, mengingat bahwa rumusan Pasal 24C ayat (1) UUD NRI Tahun 1945, khususnya frasa "memutus sengketa kewenangan lembaga negara yang kewenangannya diberikan Undang-Undang Dasar" cukup mencerminkan adanya pembatasan, maka semestinya hanya lembaga-lembaga yang termasuk kategori lembaga negara saja yang dapat menjadi para pihak dalam perkara sengketa kewenangan lembaga negara. Sesuai dengan istilah yang digunakan, yaitu lembaga negara, maka istilah dimaksud dapat diartikan sebagai lembaga yang menjalankan tugas pokok kekuasaan negara. Artinya, hanya lembagalembaga yang menjalankan tugas pokok kekuasaan negara saja yang dapat menjadi pemohon atau termohon dalam perkara sengketa kewenangan lembaga negara.

Jika model penegasan semacam ini yang dilakukan, maka dengan sendirinya tidak semua lembaga yang dapat dikategorikan sebagai lembaga negara dalam perkara sengketa kewenangan lembaga negara di MK. Sehubungan dengan itu, maka kiranya menjadi sangat urgen untuk dipikirkan bagaimana menata mekanisme penyelesaian sengketa kewenangan lembaga-lembaga di luar kategori lembaga negara, baik terkait prosedurnya maupun berkaitan dengan lembaga yang berwenang menangani sengketa dimaksud.

\section{Penutup}

Dilakukannya pengaturan masalah kewenangan penyelesaian sengketa kewenangan lembaga negara yang ditempatkan di bawah ranah kewenangan MK sebagaimana diatur dalam Pasal 24C ayat (1) UUD NRI Tahun 1945 patut dimaknai sebagai sebuah terobosan positif dalam rangka mengantisipasi munculnya konflik kewenangan antar lembaga negara. Hanya saja dalam rangka mengimplementasikan kewenangan dimaksud, ternyata masih ditemukan sejumlah masalah, khususnya terkait dengan batasan ruang lingkup dan definisi frasa "lembaga negara", serta makna frasa "yang kewenangannya diberikan oleh konstitusi sebagaimana disebutkan dalam Pasal 24C ayat (1) UUD NRI Tahun 1945. Kedua frasa dimaksud sama sekali tidak diatur secara tegas dalam UUD NRI Tahun 1945, sehingga berpotensi menimbulkan multitafsir dan pandangan beragam terkait dengan lembaga negara mana saja sesungguhnya yang memiliki kedudukan hukum (legal standing) dalam perkara sengketa kewenangan lembaga negara.

Demi efektivitas pelaksanaan kewenangan memutus perkara sengketa kewenangan lembaga negara, ke depan kiranya perlu dilakukan penegasan terkait dengan batasan ruang lingkup dan definisi frasa "lembaga negara" serta frasa "yang kewenangannya diberikan oleh Undang-Undang Dasar" sebagaimana disebutkan dalam Pasal 
24C ayat (1) UUD NRI Tahun 1945. Penegasan dimaksud seyogianya dilakukan melalui perubahan UUD NRI Tahun 1945 mengingat sumber kewenangan MK dalam memutus perkara sengketa kewenangan lembaga negara berasal dari konstitusi. Selain itu, patut dipikirkan terkait potensi konflik kewenangan antar lembaga yang kewenangannya diatur dalam tingkatan UU maupun peraturan lain. Pasalnya, sampai saat ini belum ditemukan regulasi yang mengatur lembaga mana yang berwenang menyelesaikan sengketa kewenangan lembaga yang kewenangannya diberikan peraturan lain selain UUD.

\section{DAFTAR PUSTAKA}

\section{A. Buku}

Arifin, Firmansyah, et al., 2005, Lembaga Negara dan Sengketa Kewenangan Antarlembaga Negara, Cetakan Pertama, Edisi Pertama, KRHN Bekerjasama dengan MKRI, Jakarta.

Asshiddiqie, Jimly, 2006, Model-Model Pengujian Konstitusional di Berbagai Negara, Cetakan Ketiga, Konstitusi Press, Jakarta. , 2006, Perkembangan dan Konsolidasi Lembaga Negara Pasca Reformasi, Cetakan Kedua, Sekretariat Jenderal dan Kepaniteraan MKRI, Jakarta.

Fajar, Abdul Mukhtie, 2006, Hukum Konstitusi dan Mahkamah Konstitusi, Konstitusi Press, Jakarta.

Harjono, 2009, Transformasi Demokrasi, Sekretariat Jenderal dan Kepaniteraan MKRI, Jakarta.

Kusnardi, Muh. dan Bintan Saragih, 2000, Ilmu Negara, Edisi Revisi, Gaya Media Pratama, Jakarta.

Nasrun, Andi M., 2004, Krisis Peradilan Mahkamah Agung di Bawah Soeharto, Elsam, Jakarta.

Oktaviani, Dewi, et al., 2010, Penataan Mekanisme Hubungan Antar Lembaga Negara, Pusat Kajian Kinerja Kelembagaan LAN, Jakarta.

Siallagan, Haposan dan Simamora, Janpatar, 2011, Hukum Tata Negara Indonesia, UD Sabar, Medan.

Siahaan, Maruarar, 2006, Hukum Acara Mahkamah Konstitusi Republik Indonesia, Edisi Revisi, MKRI, Jakarta.

Soemantri M, Sri, 2006, Prosedur dan Sistem Perubahan Konstitusi, Edisi Kedua, Cetakan Pertama, Alumni, Bandung.

\section{B. Artikel Jurnal}

Healy, Gavin., "Judicial Activism in the New Constitutional Court of Korea", Colum. J. Asian L, Vol. 14:213, 2000.

Lim, Jibong, "Korean Constitutional Court Standing at the Crossroads: Focusing on Real Cases and Variational Types of Decisions", Loyola of Los Angeles International and Comparative Law Review, Loyola Marymount University and Loyola Law School, Vol. 24:327, 2002.

Marzuki, H.M. Laica, "Kesadaran Berkonstitusi dalam Kaitan Konstitusionalisme", Jurnal Konstitusi, MK RI, Vol. 6 No. 3, September 2009.

\section{Makalah}

Mochtar, M. Akil, Menjaga Konsistensi Aturan Konstitusi: Peran dan Fungsi Mahkamah Konstitusi, Makalah Disampaikan Pada Program Pendidikan Reguler Angkatan XLVI, Lembaga Ketahanan Nasional (Lemhanas) Republik Indonesia, Jakarta, 19 Agustus 2011.

\section{Internet}

Asshiddiqie, Jimly, "Lembaga-Lembaga Negara, Organ Konstitusional Menurut UUD 1945", http://www.jimly.com/makalah/namafile/50/ ORGAN-ORGAN_KONSTITUSI.doc, diakses 4 April 2015.

Mahkamah Konstitusi, "Rekapitulasi Perkara Sengketa Kewenangan Lembaga Negara", http://www.mahkamahkonstitusi.go.id/index. php?page $=$ web. RekapSKLN, diakses 14 
November 2015.

Wikipedia, "Lembaga Negara", https://id.wikipedia.

org/wiki/Lembaga_Negara, diakses 20

November 2015.

\section{E. Peraturan Perundang-undangan}

Undang-Undang Dasar Negara Republik Indonesia Tahun 1945.

Undang-Undang Nomor 24 Tahun 2003 tentang Mahkamah Konstitusi sebagaimana telah diubah menjadi Undang-Undang Nomor 8 Tahun 2011 tentang Perubahan UndangUndang Nomor 24 Tahun 2003 Tentang Mahkamah Konstitusi.

Peraturan Mahkamah Konstitusi Nomor 8/ PMK/2006 Tentang Pedoman Beracara dalam Sengketa Kewenangan Konstitusional Lembaga Negara.

Putusan Mahkamah Konstitusi Nomor 002/SKLNIV/2006.

Putusan Mahkamah Konstitusi Nomor 1/ SKLN-X/2012.

The Constitution of the Republic of Korea Amanded by Oct. 29, 1987.

\section{F. Lain-lain}

Kamus Besar Bahasa Indonesia (KBBI) versi offline 1.3 .

Laporan Kinerja Mahkamah Konstitusi Tahun 2012. Laporan Tahunan Mahkamah Konstitusi Tahun 2006. 